\title{
The Role of Organizational Commitment in Employee Performance
}

\author{
Rahmad Hidayat*, Andi Nu Graha \\ Magister Management Program Pascasarjana \\ Universitas Kanjuruhan Malang \\ Malang, Indonesia \\ *rmdhdy.vb@gmail.com, andi_nu@unikama.ac.id
}

\begin{abstract}
This study puts forward a model that examines the variables of transformational leadership style, organizational commitment, and employee performance. This model intends to explore transformational leadership styles on employee performance. Specifically, this model intends to determine their relationship with organizational commitment as mediation. Data analysis used path analysis with 80 respondents using probability sampling technique. The results reveal several facts. First, transformational leadership has a significant positive effect on employee performance. Both transformational leaderships have a significant positive effect on organizational commitment. The three organizational commitments have a significant positive effect on employee performance. The four transformational leadership has a significant positive effect on employee performance through organizational commitment.
\end{abstract}

Keywords-transformational leadership, organizational commitment, employee performance

\section{INTRODUCTION}

Along with the era of globalization, business competition has become increasingly competitive, resulting in fast and uncertain changes in business and organizational environment. This condition requires every organization to improve itself in order to be able to seize opportunities and adapt to global demands. One of the efforts is by managing and utilizing human resources appropriately and optimally. This phenomenon is stated in the 3-P Concept: People, Planet, and Profit which are oriented towards sustainable development. Stated that companies desiring to thrive and be sustainable must have reliable human resources as human capital [1].

Performance refers to the level of task achievement that makes up an employee's job [2]. According to Porras and Robertson [3], vision is based on basic organizational beliefs and values and is a long-term commitment for members of the organization [4]. Organizational commitment is very important in Human Resources (HR) management for the achievement of organizational goals. In terms of utilization of HR, the Quality of Work Life (QWL) has a great influence on organizational commitment, such as financial compensation, opportunities for advancement, work environment, organizational values, job characteristics, and leadership. This study focuses on one of the factors of QWL, namely the leadership factor based on an assumption that this factor has the potential to be further explored and developed. This study attempts to broaden the understanding of transformational leadership style analysis on employee performance with organizational commitment as an intervening variable for employees of PT. Kalbe Farma, Tbk, a pharmaceutical company, which is located at $\mathrm{Jl}$ Letjen Suprapto Kav 4 Jakarta. Further research on the relationship between transformational leadership style and employee performance that is mediated by organizational commitment also needs to be done because of the research gap found in the previous studies. Organizational commitment as an attitude that reflects employee loyalty to the organization is unable to mediate the effect of transformational leadership on employee performance [5]. This research is in contrast to research conducted by Anis Eliyana that the variable of organizational commitment could mediate the effect of transformational leadership on employee performance [6]. Strengthened that Transformational leadership style and organizational commitment have a positive and significant effect on employee performance [7]. Transformational leadership style has a positive and significant effect on employee performance with organizational commitment as an intervening variable and transformational leadership directly has a positive and significant effect on employee performance [8]

\section{THEORETICAL REVIEW}

\section{A. Employee Performance}

Employee performance is the component that affects how much they (the employees) contribute to the organization [9]. Performance is a very important aspect for a company to achieve its goals.

\section{B. Transformational Leadership}

Transformational leadership is a leadership style that seeks to transform the values held by subordinates to support the vision and the goal of the organization [10]. Through the transformation of these values, it is hoped that good relations between members of the organization can be built so that a 
climate of mutual trust emerges among organizational members.

\section{Work Commitment}

Work commitment is one's identification and strong involvement in the organization [11]. Work commitment has two important components, namely attitude and the will to behave when dealing with an issue.

- Hypothesis 1: Leadership has a positive effect on employee performance. Transformational leadership style has a significant effect on employee performance at PT. Agung Automall Harapan Raya [12]. Transformational leadership style has a positive and significant effect on employee performance [8].

- Hypothesis 2: Leadership has a positive effect on work commitment, leadership style has a significant positive impact on employee performance [13] Meanwhile leadership style is hypothesized to significantly influence the three types of employee organizational commitment [14].

- Hypothesis 3: Work commitment has a positive effect on the performance. This finding implies a positive relationship between work commitment and employee performance [15]. There is a positive relationship between employee commitment and performance [16].

- Hypothesis 4: Transformational leadership style has a positive and significant effect on employee performance with work commitment as an intervening variable. The results of this study indicate that transformational leadership style and organizational commitment have a positive and significant effect on the employee's performance [7]. Transformational leadership style directly has a positive and significant effect on employee's performance.

\section{RESEARCH METHODS}

\section{A. Employee Performance}

Regarding the aspect of employee performance, it refers to Schmidt and Jackson [9] with the indicators: Quantity of work, Quality of work, Job Knowledge, Creativeness and Cooperation

\section{B. Leadership}

The aspect of leadership in this study refers to the theory of Stone et al. [17] with the indicators of Inspirational Motivation, Idealized Influence, Intellectual Stimulation and Individual Consideration.

\section{Work Commitment}

Work commitment in this study refers to Robbins and Judge [11] with the indicators of Affective Commitment, Normative Commitment, and Continuance Commitment.

\section{Sampling Technique}

The author uses Slovin technique according to Sugiyono. This research uses the Slovin formula because the number of the sample must be representative in order that the research results can be generalized and the calculation does not require a table of sample size, and it can be done with simple formulas and calculations [18]. The population in this study were leaders at PT. Kalbe Farma Tbk as many as 300 employees. The number of samples taken at PT. Kalbe Farma Tbk is 80 samples of employees.

\section{E. Data Analysis Technique}

Path Analysis is used as the data analysis technique for hypothetical testing to test the causal relationship between the research variables which consist of the direct effect between transformational leadership and employee performance, and the indirect effect, namely transformational leadership and employee performance mediated by work commitment. Hypothesis testing uses an error level of 5\% $(\alpha=0.05)$, and SPSS Ver. 20 Software is used in the analysis process.

\section{RESUlTS}

\section{A. Descriptive Analysis}

Based on gender, the majority of respondents were male (45 employees or $56.25 \%$ ), while female respondents were 35 employees $(43.75 \%)$. Based on age, the majority of respondents (39 employees) are between 40-50 years old (48.75\%), 30 employees are 30-40 years old (37.5\%), 7 employees are $>50$ years $(8.75 \%)$, and 4 employees are $26-30$ years old $(5 \%)$. (See Table 1$)$.

TABLE I. RESPONDENT CHARACTERISTICS

\begin{tabular}{|l|l|l|}
\hline \multicolumn{1}{|c|}{ Sex } & \multicolumn{1}{|c|}{ Frequency } & \multicolumn{1}{c|}{ Percentage } \\
\hline Female & 35 & $43,75 \%$ \\
\hline Male & 45 & $56,25 \%$ \\
\hline Total Age & 80 & $100 \%$ \\
\hline \multicolumn{1}{|c|}{ Frequency } & Percentage \\
\hline $26-30$ years & 4 & $5 \%$ \\
\hline $30-40$ years & 30 & $37.5 \%$ \\
\hline $40-50$ years & 39 & $48.75 \%$ \\
\hline$>50$ years & 7 & 8,75 \\
\hline Total & 80 & $100 \%$ \\
\hline
\end{tabular}

Source: Processed data 2020. 
TABLE II. DESCRIPTION OF RESEARCH VARIABLES

\begin{tabular}{|c|c|c|}
\hline Variables and Indicators & Mean & Std. Deviation \\
\hline $\begin{array}{l}\quad \text { Transformational Leadership } \\
\text { a. Inspirational Motivation } \\
\text { b. Ideal Influence } \\
\text { c. Intellectual Stimulation } \\
\text { d. Individual Consideration } \\
\end{array}$ & $\begin{array}{l}4.04 \\
3.70 \\
3.87 \\
3.72 \\
\end{array}$ & $\begin{array}{l}0.553 \\
0.647 \\
0.614 \\
0.617 \\
\end{array}$ \\
\hline $\begin{array}{l}\quad \text { Work Commitment } \\
\text { a. Affective Commitment } \\
\text { b. Normative Commitment } \\
\text { c. Continuous Commitment } \\
\end{array}$ & $\begin{array}{l}3.95 \\
3.54 \\
3.90 \\
\end{array}$ & $\begin{array}{l}0.606 \\
0.829 \\
0.643 \\
\end{array}$ \\
\hline $\begin{array}{l}\text { Employee Performance } \\
\text { a. Number of Jobs } \\
\text { b. Work quality } \\
\text { c. Work Knowledge } \\
\text { d. Creativity } \\
\text { e. Cooperative } \\
\end{array}$ & $\begin{array}{l}3.96 \\
4.04 \\
4.09 \\
4.03 \\
4.09\end{array}$ & $\begin{array}{l}0.385 \\
0.398 \\
0.438 \\
0.423 \\
0.505\end{array}$ \\
\hline
\end{tabular}

Based on table 2, transformational leadership style with inspirational motivation indicator is the variable indicator with the highest mean value. This proves that transformational leadership is able to boost the motivation of each employee. Employees will feel that they are able to give their maximum efforts to complete every given job. Transformational leadership at PT Kalbe Farma is able to boost the enthusiasm of every employee to work and accomplish their responsibility. This refers to the item that the leader is capable of boosting work enthusiasm, which is the item with highest indicator value. The lowest indicator value in the Transformational Leadership variable is the indicator of ideal influence: the leader is able to become a role model for employees. Although leaders are able to influence employees, to become role models, leaders must make some alteration. This may refer to the leader's personal judgment regardless of the level of professionalism while working at PT Kalbe Farma Tbk.

Work commitment with an indicator of effective commitment is the indicator with the highest score. The item which states that each employee adheres to the rules is the item with the highest score. This indicates that employees have an interest in working for PT Kalbe Farma Tbk because the existing regulations in the company are quite suitable and flexible for employees. The impact is that every employee wishes to continue working at the company by obliging the existing regulations. The item on the normative commitment indicator which states that it is very difficult to get a job if leaving the company is the item with the lowest indicator. This indicates that every employee at PT Kalbe Farma Tbk is quite competent in their field. Employees stay with the company based on the relationship between employees and the company, not only based on salary.

Employee performance has the highest indicator value on the job knowledge indicator, and the item is employees have a routine understanding of the given job. Understanding of routine work is necessary so that optimal performance can be achieved, and because in the future employees are able to teach understanding of work routines to new employees. Knowledge of work routines not only helps to complete every detail of the job, but also in the future with an understanding of their existing work, employees are able to provide solutions to other problems that may arise. The indicator of the number of jobs, with the item the ability to meet the number of items on demand, is the indicator with the lowest item on employee performance variable. The large market demand for Health products produced by PT Kalbe Farma Tbk requires all employees to continue to improve their performance in order to be able to serve market demand. There needs to be an adjustment to existing demands with the ability of employees so that the existing performance of PT Kalbe Farma Tbk can be maintained.

\section{B. Path Analysis}

Testing of the causal relationship between transformational leadership and employee performance mediated by work commitment was carried out using the Regression Analysis method in accordance with the tested causal relationship. Regression analysis was conducted to test 3 models: Model 1 examined the causal relationship of transformational leadership and employee performance, Model 2 investigated the causal relationship between leadership and work commitment, and Model 3 analysed the causal relationship of transformational leadership on employee performance mediated by work commitment.

TABLE III. ANALYSIS RESULT OF REGRESSION MODEL

\begin{tabular}{|c|c|c|c|}
\hline Model & Variable & $\begin{array}{c}\text { Beta } \\
\text { (Standardized } \\
\text { Coefficient) }\end{array}$ & Sig. \\
\hline Model 1 & $\begin{array}{l}\text { Performance < -- } \\
\text { Transformational } \\
\text { Leadership }\end{array}$ & 0.132 & 0.002 \\
\hline Model 2 & $\begin{array}{l}\text { Commitment }<- \\
\text { Transformational } \\
\text { Leadership }\end{array}$ & 0.290 & 0.002 \\
\hline Model 3 & $\begin{array}{l}\text { Performance }<-- \text { Work } \\
\text { Commitment } \\
\text { Performance }< \\
\text { Transformational } \\
\text { Leadership }\end{array}$ & $\begin{array}{l}0.093 \\
0.105\end{array}$ & $\begin{array}{l}0.002 \\
0.002\end{array}$ \\
\hline
\end{tabular}

Source: Processed data 2020

Based on table 3, the results of the analysis on each of the causal relationships among variables showed that transformational leadership has a positive path coefficient of 0.132 on employee performance with a significant value of 0.002 less than 0.05 , indicating that transformational leadership has a significant positive effect on employee performance. Hypothesis 1 which states that stronger transformational leadership will increase employee performance is accepted.

Based on the results of the analysis, transformational leadership has a positive path coefficient of 0.290 on work commitment with a significant value of 0.002 less than 0.05 , meaning that transformational leadership has a significant positive effect on work commitment. Hypothesis 2 which states 
that stronger transformational leadership will increase work commitment is accepted.

The results of the analysis, work commitment has a positive path coefficient of 0.093 on employee performance with a significant value of 0.002 less than 0.05 . It shows that work commitment has a significant positive effect on employee performance. Hypothesis 3 which states that stronger work commitment will increase employee performance is accepted.

The results of the analysis on each of the causal relationships between variables show that transformational leadership has a positive path coefficient of 0.105 on employee performance with a significant value of 0.002 less than 0.05 . It proves that transformational leadership has a significant positive effect on employee performance. Hypothesis 4 which states that stronger transformational leadership will improve employee performance through work commitment is accepted.

Based on the results of the Linear Regression analysis on each path of the causal relationship between variables, the path can be described in Figure 1.

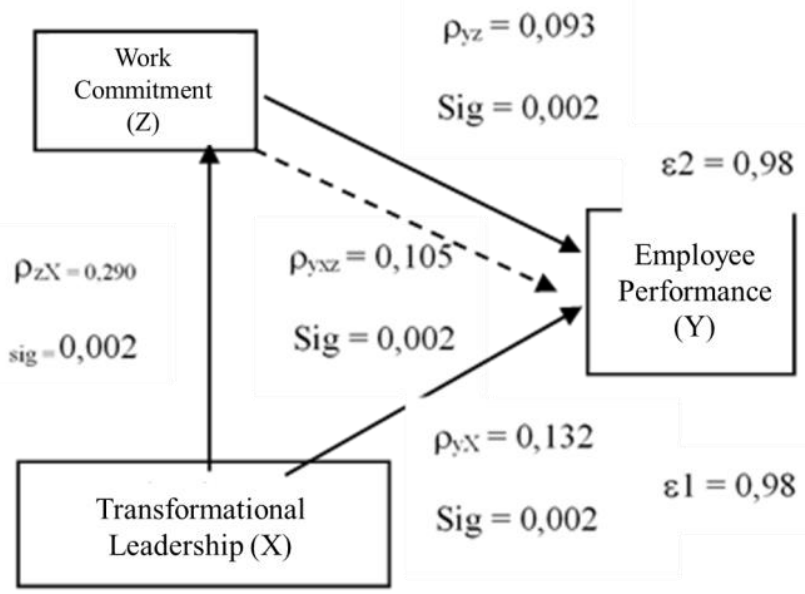

Fig. 1. Path analysis model.

All causal relationships between variables show significant positive results. Transformational leadership has a direct effect on employee performance. In addition, transformational leadership has an indirect effect on employee performance through work commitment. The direct causal relationship (indirect effect) of transformational leadership on performance is 0.132 while the indirect causal relationship (indirect effect) of leadership on performance mediated by work commitment is $0.290 \times 0.093=0.027$, then the total effect is 0.159 . All causal relationships in the model are proven to have a significant relationship, meaning that work commitment acts as a partial mediation of the relationship between transformational leadership and employee performance.

\section{DISCUSSION}

\section{A. The Effect of Transformational Leadership on Employee Performance}

From the analysis, it was found that transformational leadership has a positive and significant effect on employee performance. Transformational leadership style is able to influence employees to continue to hone their abilities in completing every job. Transformational leadership style has also proven to be influential in encouraging employees to continue to improve their performance in order to achieve the targets that have been set by the company. In addition, transformational leadership style can also encourage employees to increase their knowledge in order to get better performance at work.

Inspirational motivation, which is part of the transformational leadership style, is able to motivate employees to work optimally by using their skills. The ideal influence of a leader with transformational leadership style is also proven to have an effect on employee performance. Tasks assigned to employees are completed more quickly because employees have a role model and a figure whom they can discuss their work with. The figure of transformational leadership is also closely related to leaders who have intellectual stimulation. Here the leader gives directions to employees to increase their work knowledge to support their performance. The individual attention given by a leader is also intended so that any workrelated problems disrupting employee performance can be resolved immediately.

The results of this study support the research conducted by Paryanto [19] which stated that transformational leadership has an effect on commitment, job satisfaction, and the intention of nurses in Orthopedic Hospital Prof. Dr. R. Soeharso Surakarta to resign with the role of mediating justice and trust. This research is also in line with the research conducted by Setiawan [7] which stated that transformational leadership style and organizational commitment have a positive and significant effect on the librarian's performance. Transformational leadership styles directly have a positive and significant effect on the librarian's performance.

\section{B. The Effect of Transformational Leadership on Work Commitment}

Transformational leadership style is able to form a special bond between leaders and employees. Employees not only give their loyalty to the company, but also to the leader. In relation to effective work commitment, a transformational leadership style is able to influence employees so that they continue to uphold company regulations. In normative work commitments, transformational leadership style can influence the employees which make them willing to continue working at the company. Meanwhile, in sustainable work commitment, transformational leadership style can affect employees' feeling that one of the joys of their life is the job they have now. 
The results of this study are in line with those of the research of Sanjiwani and Suana [20] which stated that the analysis proves that transformational leadership style, job satisfaction, and organizational commitment have a simultaneous and partial effect on employee performance. The results of this study also strengthen Alkahtani's research [14] which stated that leadership style is hypothesized to significantly affect the three types of employee organizational commitment. This is also in harmony with the research conducted by Babalola [15] which found that organizational commitment is influenced by leadership style and job satisfaction.

\section{The Effect of Work Commitment on Employee Performance}

Work commitment has a positive and significant effect on employee performance based on the fact that employees have high loyalty to the company. This loyalty is not only based on the amount of salary that the employees get, but also on their commitment that the company is one of the life goals where most employees want to spend their career in the company. Through work commitment, employees continue to strive to improve their abilities in teamwork in order to support more optimal performance. Through work commitment, each employee is able to form a mutual sense of belonging to the company. This results in the ability of employees to support each other in order to create optimal performance.

Affective commitment is a variable of employee's emotional attachment to the organization. In this study, employee affective commitment is included in the good criteria indicated by the feeling of being part of the organization and effort to improve careers in the organization. Continuous commitment in this study is indicated by employees' good acceptance of the rewards given by the organization regardless of the size because they consider that they will lose good facilities if they leave the organization. Normative commitment is a feeling of obligation that employees have to be in the organization. The employees have a strong desire to continue working for the company. Most employees have worked for a relatively long period of time. This also strengthens the relationship between existing organizational commitments and current performance.

The results of this study are in line with those of research by Abasilim et al. [16] which stated that there is a moderate positive relationship between transformational leadership style and employee commitment to employee performance. This research is also in line with the research conducted by Hafeez et al. [21] which stated that there is a significant relationship between transactional leadership style and transformational leadership style and organizational commitment to organizational performance.

\section{The Influence of Transformational Leadership on Employee Performance through Work Commitment}

The stronger the leadership style in the company, the better the employee performance in the company. Better leadership skills will increase work commitment in the company, and with a strong work commitment, conducive work atmosphere will be formed. This will strengthen the optimization of employee performance. Transformational leadership style is able to influence employees in their effort to complete any given job. Through transformational leadership, employees get a comfortable and conducive working atmosphere. Work atmosphere is one of the factors for employees to stay or resign from the company they are currently working for. Through a comfortable working atmosphere, employees are also able to reach every job target set by the company. Through transformational leadership, the employees also feel that they are appreciated for every detail of their work. Achievement or awards, apart from being a form of company appreciation for the employees' successful performance, is also a form of emotional bonding between the company and its employees. Optimal performance results from each employee's knowledge of the details of the work. Through transformational leadership, the leader seeks to push employee knowledge on how to solve problems with new methods. Employee knowledge is not only limited to work routines that have been carried out. Through transformational leadership, a leader also provides several tasks that are not routinely done.

The results of this study, however, are not in line with the research conducted by Mubarak [22] which stated that transformational leadership style and organizational culture also have a significant and positive effect on organizational commitment. Finally, there are significant and positive effects of organizational commitment. Research also shows that Organizational Commitment has a mediating role between transformational leadership style, organizational culture and employee performance. This research is also in line with research conducted by Lalily [12] which stated that transformational leadership style has a significant effect on the performance of employees of PT. Agung Automall Harapan Raya, and organizational commitment has a significant effect on the performance of employees of PT. Agung Automall Harapan Raya.

\section{CONCLUSION}

The results of this study indicate that transformational leadership style has a positive and significant effect on employee performance at PT Kalbe Farma Tbk. The leaders are highly competent so that employees' trust in any decisions and methods in solving work-related problems is also high. Leaders have sufficient knowledge and work experience. Therefore, employees fully believe in all policies implemented by the leaders to optimize employee performance. The current transformational leadership style is able to get a stronger influence on work commitment. The existing work commitment is able to create high employee loyalty to the company. This is surely advantageous as the employee performance is more optimal. Transformational leadership style plays a role in improving employee performance through work commitment. This indicates that transformational leadership style has the indicators of high self-management and 
ability to form strong work commitment. A strong work commitment is reflected in working innovatively and taking risks with attention to detail. Strong work commitment is reflected by having high confidence and loyalty to the company.

\section{REFERENCES}

[1] H.V. Rivai dan S.E. Jauvani, Manajemen Sumber Daya Manusia untuk Perusahaan. Jakarta: Grafindo Persada, 2011.

[2] H. Simamora, Manajemen Sumberdaya Manusia. Yogyakarta: Sekolah Tinggi Ilmu Ekonomi YKPN, 2006.

[3] J.I. Porras and P.J. Robertson, "Organization development: Theory, practice, and research," In M.D. Dunnette and L.M. Hough (Eds.), Handbook of industrial and organizational psychology (2nd ed., vol. 3, pp. 719-822). Palo Alto, CA: Consulting Psychology Press, 1993.

[4] F. Mas'ud, Survai Diagnosis Organisasional (Konsep dan Aplikasi). Semarang: Badan Penerbit Universitas Diponegoro, 2004.

[5] K.A.Y. Sari, "Pengaruh kepemimpinan transformasional terhadap kepuasan kerja dan komitmen organisasional," Jurnal Ekonomi dan Bisnis Universitas Udayana, vol. 6, no. (1), pp. 1-28, 2017.

[6] A. Eliyana and S. Ma'arif, "Job satisfaction and organizational commitment effect in the transformational leadership towards employee performance," European Research on Management and Business Economics, vol. 25, no. (3), pp. 144-150, 2019.

[7] Setiawan, Hubungan antara gaya kepemimpinan transformasional komitmen organisasional dengan kinerja pustakawan di lingkungan perpustakaan Universitas Negeri Malang. Malang: Tesis, Universitas Islam Maulana Malik Ibrahim. Malang, 2015.

[8] M.I. Sina, Analisis Pengaruh kepemimpinan transformasional terhadap kinerja karyawan dengan komitmen organisasi sebagai variabel intervening (Studi pada PT. Cipta Krida Bahari Divisi Integrated Logistic Services Kantor Cakung). Semarang: Skripsi. Universitas Diponegoro, 2013.

[9] G. Schmidt and L. Jackson, "Managing paradoxes in change: Six steps for building a balanced culture," The Conference Board-Executive Action Series, no. (162), 2005.

[10] B.J. Avolio, B.M. Bass, and D.I. Jung, "Re-examining the components of transformasional and transactional leadership using the multifactor leadership questionnaire," Journal of Occupational and Organizational Psychology, vol. 60, no. (1), pp. 421-449, 2004.
[11] S.P. Robbins dan D. Judge, Perilaku Organisasi. Jakarta: Salemba Empat, 2007.

[12] N. Lalily, "Pengaruh kepemimpinan transformasional dan komitmen organisasi terhadap kinerja karyawan PT Agung Auto Mall,” Jom FISIP, vol. 4, no. (2), 2017.

[13] A. Basit, V. Sebastian, and Z. Hassan, "Impact of Leadership style on Employee Performance (a case study on a private organization in Malaysia)," International Journal of Accounting \& Business Management, vol. 5, no. (2), pp. 112-130, 2017.

[14] A.H. Alkahtani, "The Influence of Leadership Styles on Organizational Commitment: The Moderating Effect of Emotional Intelligence," Journal Business and Management Studies, vol. 2, no. 1, March 2016.

[15] S.S. Babalola, "The Effect Of Leadership Style, JobSatisfaction And Employee-Supervisor Relationship On Job Performance And Organizational Commitment," The Journal of Applied Business Research, vol. 32, no. 3, 2016.

[16] U.D. Abasilim, D.E. Gberevbie and O.A. Osibanjo, "Leadership Styles and Employees' Commitment: Empirical Evidence From Nigeria," Journal SAGE, vol. 9, no. (3), September 2019.

[17] Stone, G. A., Russell, R. F., \& Patterson, K. (2004). Transformational versus servant leadership: A difference in leader focus. Leadership \& Organization Development Journal, 25(4), 349-361.

[18] Sugiyono, Metode Penelitian Bisnis. Cetakan Ke 8. Bandung: CV. Alfabeta, 2011

[19] P. Paryanto, "pengaruh gaya kepemimpinan transformasional pada komitmen, kepuasan kerja dan niat pindah kerja dengan peran mediasi keadilan dan kepercayaan di rso prof. Dr. R. Soeharso surakarta," Jurnal Manajemen Dayasaing, vol. 18, no. (1), pp. 20-29, 2017.

[20] I.M.A. Sanjiwani dan I.W. Suana, "Pengaruh Kepemimpinan Transformasional, Kepuasan Kerja Dan Komitmen Organisasi Terhadap Kinerja Karyawan Bagus Hayden Hotel Kuta, Bali,” E-Jurnal Manajemen, vol. 5, no. (2), 2016.

[21] M.H. Hafeez, S.M.H. Rizvi, A. Hasnain, and A. Mariam, "Relationship of leadership styles, employees commitment and organization performance (a study on customer support representatives)," European Journal of Economics, Finance and Administrative Sciences, vol. 1, no. (49), pp. 133-143, 2012.

[22] S. Mubarak, "Developing a theory-based information security management framework for human service organizations," Journal of Information, Communication and Ethics in Society, vol. 14, no. 3, pp 254-271, 2016. 